\title{
Expression analysis of the ssgA gene product, associated with sporulation and cell division in Streptomyces griseus
}

\author{
Shinichi Kawamoto, ${ }^{1}$ Hajime Watanabe, ${ }^{1}$ Andrew Hesketh, ${ }^{1}$ \\ Jerald C. Ensign ${ }^{2}$ and Kozo Ochi ${ }^{1}$ \\ Author for correspondence: Shinichi Kawamoto. Tel: +8129838 8124. Fax: +81298387996. \\ e-mail: taishi@ss.nfri.affrc.go.jp
}

\footnotetext{
1 National Food Research Institute, 2-1-2 Kannondai, Tsukuba, Ibaraki 305, Japan

2 Department of Bacteriology, 1550 Linden Drive, University of Wisconsin-Madison, Madison, WI 53706, USA
}

\begin{abstract}
The ssgA gene of Streptomyces griseus B2682, when present in high copy number, results in both suppression of sporulation and fragmented growth of mycelia. Western analysis with polyclonal antibodies against the gene product (SsgA) revealed a close correlation between SsgA accumulation and the onset of sporulation in wild-type cells. The protein was only detected in the cytoplasm. Certain developmental mutants of S. griseus (afs, re/C and brgA) which are defective in aerial mycelium formation in solid culture and submerged spore formation in liquid culture failed to accumulate SsgA. The SsgA protein appeared shortly $(1 \mathrm{~h})$ after nutritional shift-down of strain B2682 cells. afs mutant cells sporulated and expressed SsgA only when Afactor was present both before and after nutritional shift-down. Introduction of the ssgA gene in a low-copy-number vector into strain B2682 resulted in fivefold overexpression of SsgA, and was accompanied by fragmented growth of mycelia and suppression of submerged spore formation (in liquid culture) and aerial mycelium formation (in solid culture). Streptomycin production was not inhibited. In a control experiment, a nonfunctional ssgA gene possessing a frameshift mutation near its $\mathbf{N}$-terminus had no effect on either growth or sporulation. It is proposed that the ssgA gene product plays a role in promoting the developmental process of S. griseus.
\end{abstract}

Keywords: Streptomyces griseus, sporulation, cell division, ssgA gene

\section{INTRODUCTION}

Streptomycetes are unique bacteria which grow vegetatively as multinucleoidal branched substrate mycelia containing occasional cross-walls. Reproduction occurs by the synchronous and regularly spaced septation of specialized aerial hyphae to form uninucleate dormant spores (Chater, 1984, 1989). Most Streptomyces species sporulate only during growth on solid media, presumably in response to nutrient depletion signals, i.e. a decrease in intracellular GTP pool size (Ochi, 1987a, b, 1990; Itoh et al., 1996). Sporulation in Streptomyces is a complicated process involving expression of genes which are both temporally and spatially regulated (Chater, 1984, 1993).

Studies of sporulation in most streptomycetes are hampered by asynchronous growth, because cultures

Abbreviation: MBP, maltose-binding protein. contain a mixture of young and senescent vegetative mycelia and hyphae in various stages of the sporulation process. Streptomyces griseus, however, sporulates relatively synchronously over a short time period when cultured in shaken submerged conditions (Kendrick \& Ensign, 1983; Ensign, 1988). Thus, this organism provides a feasible system for the physiological and genetic study of sporulation, as demonstrated in previous physiological (Ochi, 1987a, b; Kendrick \& Ensign, 1983) and molecular genetic (Babcock \& Kendrick, 1988, 1990) studies.

S. griseus strain NRRL B2682 sporulates after approximately $30 \mathrm{~h}$ of growth in a semi-defined liquid medium (Ensign, 1988; Kawamoto \& Ensign, 1995a). On inclusion of casein hydrolysate $(1 \%, \mathrm{w} / \mathrm{v})$ and yeast extract $(1 \%, \mathrm{w} / \mathrm{v})$ in the medium, the organism grows profusely as branched mycelia but does not sporulate. Kawamoto \& Ensign (1995a) isolated mutants that sporulate in such a nutritionally rich medium, in which sporulation is normally suppressed. Transfer of six 
different genomic DNA fragments in high-copy-number plasmids from the parent to mutant cells caused the mutants to exhibit the original phenotype of not sporulating in the rich medium. One of the DNA clones (named $s s g A$ ) was further analysed and the $s s g A$ gene was found by DNA sequence analysis to encode an acidic protein of approximately $15 \mathrm{kDa}$ which showed no significant sequence homology to known proteins (Kawamoto \& Ensign, 1995b). The ssgA gene, when present in high copy number in the parent cells, not only resulted in the suppression of sporulation but also caused the cells to grow in a fragmented rather than mycelial fashion. Thus, the $s s g A$ gene product was proposed to act both as a positive effector of cell division and as a negative effector of sporulation (Kawamoto \& Ensign, 1995b). The aim of the present study was to clarify further the possible role of the $s s g A$ gene product (SsgA) in relation to both cell division and morphological development by investigating its expression using Western analysis with an anti-SsgA serum.

\section{METHODS}

Bacterial strains, plasmids and growth conditions. Strains and plasmids are listed in Table 1. The afs mutant BB51, defective in A-factor synthesis, was obtained from strain $\mathrm{B} 2682$ by incubating the cells at $36^{\circ} \mathrm{C}$ as described previously (Ochi, 1987b). DM1 medium, a glucose/ammonium/mineral salts medium, contained $25 \mathrm{mM}$ MOPS (pH $7 \cdot 2$ with $\mathrm{KOH}$ ), $5 \mathrm{mM}\left(\mathrm{NH}_{4}\right)_{2} \mathrm{SO}_{4}, 0.5 \mathrm{mM} \mathrm{MgSO}, 0 \cdot 1 \%(\mathrm{w} / \mathrm{v})$ casein hydrolysate (Hy-Case SF, Sigma), $50 \mathrm{mM}$ glucose, $10 \mathrm{mM}$ $\mathrm{K}_{2} \mathrm{HPO}_{4} / \mathrm{KH}_{2} \mathrm{PO}_{4}$ buffer $(\mathrm{pH} 7 \cdot 0), 67.5 \mu \mathrm{M} \mathrm{CaCl}, 18 \mu \mathrm{M}$ $\mathrm{FeSO}_{4}, 25 \mu \mathrm{M} \mathrm{MnSO}_{4}$ and $0.43 \mu \mathrm{M} \mathrm{ZnSO}_{4}$. Glucose and the potassium phosphate buffer were autoclaved separately. DMCY medium contained $1 \%(\mathrm{w} / \mathrm{v}) \mathrm{Hy}$-Case SF and $1 \%$ $(\mathrm{w} / \mathrm{v})$ yeast extract (Difco) in addition to the components of DM1. GYM medium contained (per litre): $4 \mathrm{~g}$ glucose, $4 \mathrm{~g}$

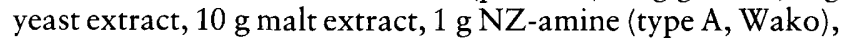
$2 \mathrm{~g} \mathrm{NaCl}, 5 \mathrm{mg} \mathrm{CuSO}{ }_{4} .5 \mathrm{H}_{2} \mathrm{O}, 7.5 \mathrm{mg} \mathrm{FeSO}_{4} .7 \mathrm{H}_{2} \mathrm{O}, 3.6 \mathrm{mg}$ $\mathrm{MnSO}_{4} \cdot 5 \mathrm{H}_{2} \mathrm{O}, 15 \mathrm{mg} \mathrm{CaCl} \cdot 2 \mathrm{H}_{2} \mathrm{O}$, and $9 \mathrm{mg} \mathrm{ZnSO} \cdot 7 \mathrm{H}_{2} \mathrm{O}$ (adjusted to $\mathrm{pH} \mathrm{7.3}$ with $\mathrm{NaOH}$ ). For preparation of protoplasts or plasmid DNA, cells were grown in Bacto-tryptic soy broth supplemented with $10 \%$ (w/v) sucrose, $5 \mathrm{mM} \mathrm{MgCl}_{2}$ and $0.3 \%(\mathrm{w} / \mathrm{v})$ glycine. Regeneration medium, SpMR, was described previously (Babcock \& Kendrick, 1988). Soluble starch/polypeptone/yeast extract (SPY) medium contained (per litre): $30 \mathrm{~g}$ soluble starch, $2 \mathrm{~g}$ yeast extract, $2 \mathrm{~g}$ $\mathrm{MgSO}_{4} .7 \mathrm{H}_{2} \mathrm{O}, 30 \mathrm{~g}$ polypeptone, $5 \mathrm{mg} \mathrm{CuSO}{ }_{4} .5 \mathrm{H}_{2} \mathrm{O}, 7.5 \mathrm{mg}$ $\mathrm{FeSO}_{4} \cdot 7 \mathrm{H}_{2} \mathrm{O}, 3 \cdot 6 \mathrm{mg} \mathrm{MnSO} \mathrm{Mn}_{4} \cdot 5 \mathrm{H}_{2} \mathrm{O}, 15 \mathrm{mg} \mathrm{CaCl} \mathrm{Ca}_{2} \cdot 2 \mathrm{H}_{2} \mathrm{O}$ and $9 \mathrm{mg} \mathrm{ZnSO} 4.7 \mathrm{H}_{2} \mathrm{O}$ (adjusted to $\mathrm{pH} 7 \cdot 3$ with $\mathrm{NaOH}$ ). SPY medium, used for streptomycin production, contained $2 \%$ (w/v) $\mathrm{MgSO}_{4} \cdot 7 \mathrm{H}_{2} \mathrm{O}$. Streptomyces cultures were incubated at $30^{\circ} \mathrm{C}$, unless otherwise stated. Spores were inoculated into the appropriate media at a final concentration of $2 \times 10^{7}$ to $5 \times 10^{7}$ spores $\mathrm{ml}^{-1}$. Cultivation was performed on a rotary shaker (200 r.p.m.) using $100 \mathrm{ml}$ of the medium in a $500 \mathrm{ml}$ flask containing a coiled stainless steel wire to prevent clump formation. For selection of transformants, antibiotics were added to the growth media to a final concentration of $2.5 \mu \mathrm{g}$ $\mathrm{ml}^{-1}$ (liquid media) or $10 \mu \mathrm{g} \mathrm{ml}^{-1}$ (solid media) for thiostrepton and/or $10 \mu \mathrm{g} \mathrm{ml}^{-1}$ (liquid media) or $25 \mu \mathrm{g} \mathrm{ml}^{-1}$ (solid media) for hygromycin. E. coli was grown with shaking in Luria broth or on Luria agar at $37^{\circ} \mathrm{C}$. When necessary, ampicillin and IPTG were added to the media to a final concentration of $50 \mu \mathrm{g}$ $\mathrm{ml}^{-1}$ and $0.5 \mathrm{mM}$, respectively.
Physiological methods. For streptomycin production, spores or cells of B2682 (or its transformants previously grown on selective agar plates) were inoculated into SPY medium followed by incubation at $30^{\circ} \mathrm{C}$ for $3 \mathrm{~d}$. Then $3 \mathrm{ml}$ aliquots of the culture were used to inoculate $100 \mathrm{ml}$ SPY medium containing $2 \% \mathrm{MgSO}_{4} \cdot 7 \mathrm{H}_{2} \mathrm{O}$, followed by incubation at $25^{\circ} \mathrm{C}$ for $3 \mathrm{~d}$. Streptomycin was assayed as described previously (Ochi, 1986). A-factor was prepared by extracting the culture broth of $S$. griseus IFO13189 with ethyl acetate. The concentration of A-factor in the preparation was determined by bioassay (Ochi, 1987b) with $S$. griseus mutant BB51, defective in A-factor synthesis. Authentic A-factor was a gift from K. Ueda. Nutritional shift-down was performed as described previously (Ochi, 1987a), except that cells grown to mid-exponential phase (approx. $1.5 \mathrm{mg}$ dry cell weight $\mathrm{ml}^{-1}$ ) in DMCY medium were filtered and transferred to the same volume of DM 1 medium without $0 \cdot 1 \%$ casein hydrolysate. In plate cultures, a $0 \cdot 1 \mathrm{ml}$ spore suspension (approximately $2 \times 10^{8}$ spores) was spread on a cellophane sheet (diameter $8 \mathrm{~cm}$; UV-sterilized) previously placed on the agar medium. At various times the cellophane sheet with mycelia was removed, and the cells were collected by scraping off with a spatula. Harvested cells were stored at $-30^{\circ} \mathrm{C}$ until use. The intracellular concentrations of ppGpp and other nucleotides were assayed by HPLC as described by Ochi (1987a). Spore titres were determined by direct counting in a Petroff-Hauser counting chamber using phase-contrast optics. Samples were sonicated for $5 \mathrm{~min}$ prior to counting.

Preparation of crude extract. Cells were suspended in TGE buffer containing $10 \mathrm{mM}$ Tris $/ \mathrm{HCl}(\mathrm{pH} 7 \cdot 0), 1 \mathrm{mM}$ EDTA, $1 \mathrm{mM}$ dithiothreitol and $10 \%(\mathrm{v} / \mathrm{v})$ glycerol. The cell suspensions $\left(0.5 \mathrm{~g} \mathrm{cells} \mathrm{ml}^{-1}\right)$ were sonicated for $3 \mathrm{~min}$ in an icecold bath. Cell debris was then removed by centrifugation at $10000 \mathrm{~g}$ for $60 \mathrm{~min}$, and the resulting supernatant was used as a crude extract for Western analysis. Crude extracts thus prepared typically contained $2-10 \mathrm{mg}$ protein $\mathrm{ml}^{-1}$. In a cellfractionation experiment, the crude extract was ultracentrifuged at $75000 \mathrm{~g}$ for $60 \mathrm{~min}$. The supernatant served as a cytoplasmic fraction, whilst the pellet was resuspended in $0 \cdot 2$ vol. TGE buffer with brief sonication and used as a membrane fraction. All procedures were performed at $4{ }^{\circ} \mathrm{C}$.

PAGE and immunoblotting. SDS-PAGE was performed using a $12 \%$ gel according to the method of Laemmli (1970). Proteins on the gel were visualized using Commassie blue. For immunoblotting, proteins separated on the gel were transferred to an Immobilon-P membrane (Millipore) using a semidry blotting apparatus (Atto) with blotting buffer consisting of $25 \mathrm{mM}$ Tris base, $192 \mathrm{mM}$ glycine, and $20 \%(\mathrm{v} / \mathrm{v})$ methanol (pH 8.3). An electric field of $2 \mathrm{~mA} \mathrm{~cm}^{-2}$ was applied for $1 \mathrm{~h}$. Western blots were developed using the ECL Western blotting chemiluminescent detection system (Amersham) as specified by the manufacturer. The polyclonal anti-SsgA serum, prepared as described below, was used as the primary antibody at a dilution of 1:5000. Incubation of the luminol-saturated blot in the presence of chemical enhancers and subsequent exposure to X-ray film were performed at room temperature.

General DNA techniques and transformation. Restriction and modifying enzymes were used according to the manufacturer's recommendations. Plasmid DNA was prepared by alkaline lysis (Kieser, 1984). DNA fragments were purified from the agarose gels by using a Gene Clean kit (Bio101). Nucleotide sequencing was done by the dideoxynucleotide chaintermination method, using a Sequenase version 2.0 kit (US Biochemicals), alkali-denatured supercoiled plasmid DNA and $\left.{ }^{35} \mathrm{~S}\right] \mathrm{dCTP} \alpha \mathrm{S}$ (sp. act. $1000 \mathrm{Ci} \mathrm{mmol}^{-1}, 37 \mathrm{TBq} \mathrm{mmol}^{-1}$, DuPont). 7-Deaza-dGTP was substituted for dGTP to resolve 
Table 1. Bacterial strains and plasmids

\begin{tabular}{|c|c|c|}
\hline Strain or plasmid & Description & Source or reference \\
\hline \multicolumn{3}{|l|}{ S. griseus } \\
\hline B2682 & Wild-type & Kendrick \& Ensign (1983) \\
\hline IFO13189 & Wild-type & Ochi $(1987 a)$ \\
\hline SY1 & Spontaneous mutant of $\mathrm{B} 2682$ that sporulates in rich media & Kawamoto \& Ensign (1995a) \\
\hline BB51 & afs mutant of B2682 & This study \\
\hline No. 14 & afs mutant of IFO13189 & Ochi $(1987 b)$ \\
\hline $3-3$ & relC mutant of IFO13189 & Ochi $(1990)$ \\
\hline No. 4 & $\operatorname{brg} A 1$ (formerly $a b a-1$ ) of IFO13189 & Ochi et al. (1992) \\
\hline \multicolumn{3}{|l|}{ E. coli } \\
\hline DH $5 \alpha$ & Laboratory K-12 strain & \\
\hline \multicolumn{3}{|l|}{ E. coli plasmids } \\
\hline pUWB & $\begin{array}{l}\text { pGEM-3Zf }(-)\left(A m p^{r}\right) \text { with a } 1.5 \mathrm{~kb} \text { Bam HI-PstI fragment } \\
\text { containing } s s g A\end{array}$ & Kawamoto \& Ensign (1995b) \\
\hline $\mathrm{pUW} \Delta \mathrm{SA}$ & $\begin{array}{l}\text { pGEM-3Zf }(-)\left(A m p^{r}\right) \text { with same fragment as in pUWB but with a } \\
28 \text { bp deletion between SacI sites resulting in a frameshift mutation } \\
\text { in the } s s g A \text { gene }\end{array}$ & This study \\
\hline pMAL-c & $\begin{array}{l}\text { pBR322 }\left(A m p^{r}\right) \text { derived vector for overexpression of a fusion } \\
\text { protein with a maltose binding protein }(\mathrm{MBP})\end{array}$ & New England Biolabs \\
\hline pMGC1 & $\begin{array}{l}\text { pMAL-c }\left(A m p^{r}\right) \text { derivative containing a MBP-SsgA fusion protein } \\
\text { gene }\end{array}$ & This study \\
\hline \multicolumn{3}{|c|}{ Streptomyces plasmids } \\
\hline pIJ941 & Low-copy-number cloning vector $\left(\mathrm{Hyg}^{r} \mathrm{Tsr}^{\mathrm{r}}\right)$ & Lydiate et al. (1985) \\
\hline $\mathrm{pV} 1$ & $\begin{array}{l}\text { pIJ941 derivative }\left(\operatorname{Hyg}^{r} \operatorname{Tsr}^{r} A m p^{r}\right) \text { containing pBluescript } \mathrm{SK}(+) \\
\text { sequence }\end{array}$ & This study \\
\hline pIJ702 & High-copy-number cloning vector $\left(\mathrm{Tsr}^{\mathrm{r}} \mathrm{Mel}^{+}\right)$ & Katz et al. (1983) \\
\hline pLSA & $\begin{array}{l}\mathrm{pV} 1\left(\mathrm{Tsr}^{\mathrm{r}} \mathrm{Hyg}^{\mathrm{s}} \mathrm{Amp} \mathrm{p}^{\mathrm{r}}\right) \text { with a } 1.5 \mathrm{~kb} \text { EcoRI-PstI fragment } \\
\text { containing } s s g A\end{array}$ & This study \\
\hline $\mathrm{pL} \Delta \mathrm{SA}$ & $\begin{array}{l}\mathrm{pV} 1\left(\mathrm{Tsr}^{\mathrm{r}} \mathrm{Hyg}^{\mathrm{s}} \text { Amp }{ }^{\mathrm{r}}\right) \text { with a } 1.5 \mathrm{~kb} \text { EcoRI-PstI fragment } \\
\text { containing the mutated ssgA from pUW } \Delta \mathrm{SA}\end{array}$ & This study \\
\hline pMSA & $\begin{array}{l}\left.\text { plj702 (Tsr }{ }^{\mathrm{r}} \mathrm{Mel}^{-}\right) \text {with a } 1.5 \mathrm{~kb} \text { BamHI-Pst I fragment containing } \\
\text { ssgA }\end{array}$ & This study \\
\hline
\end{tabular}

ambiguities and compressions. Transformation of $S$. griseus was essentially the same as described previously (Hopwood $e t$ al., 1985; Kawamoto \& Ensign, 1995a), except that the recombinant plasmid DNA prepared from E. coli was alkalidenatured prior to use. Typically, 5-10 $\mu \mathrm{g}$ plasmid DNA in $100 \mu \mathrm{l}$ TE buffer $(10 \mathrm{mM}$ Tris $/ \mathrm{HCl} \mathrm{pH} 7 \cdot 5$ and $1 \mathrm{mM}$ EDTA) was treated with $10 \mu \mathrm{l}$ of an alkaline solution consisting of $2 \mathrm{M}$ $\mathrm{NaOH}$ and $2 \mathrm{mM}$ EDTA. After incubation at $37^{\circ} \mathrm{C}$ for $30 \mathrm{~min}$ the DNA solution was neutralized by addition of $10 \mu \mathrm{l} 3 \mathrm{M}$ sodium acetate $(\mathrm{pH} 5 \cdot 2)$ and then precipitated with ethanol. The resulting DNA pellet was dissolved in $10 \mu \mathrm{l}$ TE buffer and then used for transformation. This procedure was found to enhance the transformation efficiency of the plasmid DNA more than 10 -fold. Transformation of E. coli was performed by standard procedures (Sambrook et al., 1989).

Construction of recombinant plasmids. pV1 was constructed using pIJ941 (Lydiate et al., 1985) fragments produced following digestion with BamHI and Xhol. The fragments $(23.7 \mathrm{~kb}$ and $1.3 \mathrm{~kb})$ were dephosphorylated and ligated to a pBluescript $\mathrm{SK}(+)$ vector (Stratagene) digested with BamHI and $\mathrm{XboI}$ in the polylinker region. The ligated products were introduced into E. coli $\mathrm{DH} 5 \alpha$ and the transformants were selected for ampicillin resistance. The recombinant plasmids were screened for the presence of the larger $23.7 \mathrm{~kb}$ pIJ941 fragment insert by restriction analysis. The plasmid pV1 is an E. coli-Streptomyces shuttle vector which possesses the ampicillin resistance gene as a selective marker in $E$. coli, and the thiostrepton resistance or hygromycin resistance gene as a selective marker in Streptomyces. Like pIJ941, pV1 retains the same unique restriction sites for gene cloning (BamHI, $B g l \mathrm{II}$, ClaI, EcoRV, EcoRI and PstI). The copy number of the plasmid pV1 is estimated to be as low as $5-10$ copies per genome in $S$. griseus, and 1-2 copies per genome in $S$. coelicolor (S. Kawamoto, unpublished results). The Streptomyces vector plasmid pIJ702, which is commonly used for gene cloning, is estimated to be present at 40-300 copies per genome (Katz et al., 1983).

pMSA and pLSA were constructed as follows. For pMSA, the $1.5 \mathrm{~kb} \mathrm{Bam} \mathrm{HI}-P s t \mathrm{I}$ insert from pUWB which contains the $s s g$ gene sequence (Kawamoto \& Ensign, 1995b; see Fig. 1) was gel-purified and ligated to a gel-purified $5 \cdot 1 \mathrm{~kb}$ fragment resulting from the digestion of pIJ702 with $B g l \mathrm{II}$ and PstI. The ligated products were introduced into $S$. griseus B2682 and the transformants were selected for thiostrepton resistance and for non-production of melanin (by insertional inactivation). pMSA was examined for the presence of the correct insert by restriction analysis. For construction of pLSA, a $1.5 \mathrm{~kb}$ fragment containing $s s g A$ was produced by digestion of $\mathrm{pUWB}$ 


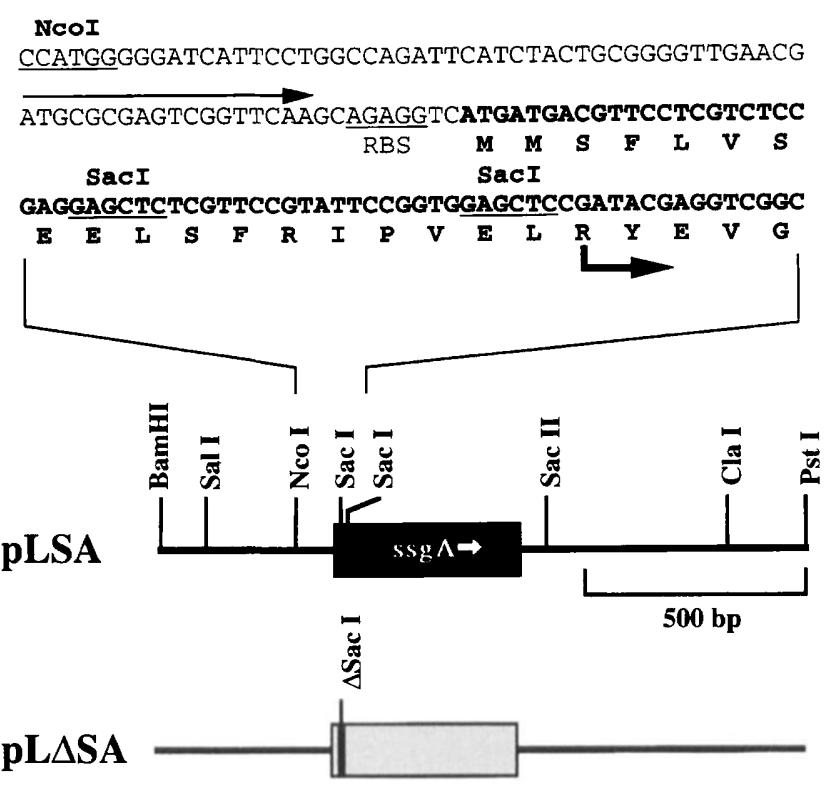

Fig. 1. Restriction map and structure of the $S$. griseus ssgA gene region. Partial nucleotide and amino acid sequences of the $s s g A$ gene relevant in this study, and the structure of plasmid pL $\triangle S A$, which has a frameshift mutation (28 bp deletion between Sacl sites) within the ssgA gene, are also shown. The initiation codon ATG shown in this study differs from that previously reported (Kawamoto \& Ensign, 1995b) and is preferred because it is preceded by a more probable ribosome-binding site (RBS, underlined below the nucleotide sequence). The oligonucleotide primer used for DNA sequencing to confirm the mutated ssgA gene is shown by the thin arrow above the nucleotide sequence. The bold arrow below the amino acid sequence represents the portion of the SsgA ORF included in the fusion protein used for the preparation of the anti-SsgA serum (see Methods). The DDJB/EMBL/GenBank accession number of the ssgA gene is D50051.

with EcoRI and PstI in the polylinker region of the vector sequence and gel-purified. This fragment was ligated to the dephosphorylated pV1 fragments $(26.1$ and $0.6 \mathrm{~kb})$ obtained following digestion with EcoRI and PstI. The single EcoRI site lies within the hygromycin resistance gene of $\mathrm{pV} 1$. The ligated products were introduced into $E$. coli $\mathrm{DH} 5 \alpha$ and the transformants were selected for ampicillin resistance. pLSA was examined for the presence of the correct insert by restriction analysis.

For construction of pL $\Delta \mathrm{SA}, \mathrm{pUW} \Delta \mathrm{SA}$ was first prepared as follows. pUWB was digested with SacI, cutting at sites in the polylinker region of the vector sequence, and also at positions between the 9th and 10th codons and between the 17th and 18 th codons of the $s s g A$ polypeptide sequence (see Fig. 1 ). The products were blunt-ended by removal of the $3^{\prime}$ overhangs using T4 DNA polymerase, and then digested with $\mathrm{BamHI}$ and PstI. The resulting $416 \mathrm{bp}$ and $1069 \mathrm{bp}$ fragments, containing the $\mathrm{N}$ - and C-terminal portions of the ssg $A$ gene respectively, were gel purified and ligated into the vector pGEM-3Zf $(-)$ that had been digested with BamHI and PstI. The ligated products were introduced into E. coli DH5 $\alpha$ and the transformants were selected for ampicillin resistance and for white colony colour. pUWASA was examined for the presence of the correct insert by restriction analysis. This plasmid is expected to have a 28 bp deletion between the SacI sites, resulting in a frameshift mutation in the $s s g A$ gene (see Fig. 1). The mutation in pUW $\Delta S A$ was verified by nucleotide sequencing with a custom-made primer, 5'-ATGCGCGAGTCGGTTCAA-3' (see Fig. 1). pUWASA was digested with EcoRI and $P s t \mathrm{I}$ in the polylinker region of the vector sequence and the $1.5 \mathrm{~kb}$ fragment containing the mutated $s s g A$ gene was gel-purified. This fragment was ligated to the dephosphorylated $26 \cdot 1 \mathrm{~kb}$ pV1 fragment obtained following digestion with EcoRI and PstI, yielding pLASA.

Transformation of $S$. griseus B2682 with the pLSA or pL $\Delta$ SA plasmid DNA from E. coli transformants was performed as described above, and transformants were selected for thiostrepton resistance and for hygromycin sensitivity (by insertional inactivation). The presence of pLSA or pLASA was confirmed by restriction analysis.

pMGC1, expressing the maltose-binding protein (MBP)-SsgA fusion protein, was constructed as follows. pUWB was digested with SacI (see above and Fig. 1), blunt-ended by removing the $3^{\prime}$ overhangs using T4 DNA polymerase, and then digested with HindIII (cutting at the polylinker region of the vector sequence). The resulting $1073 \mathrm{bp}$ fragment containing the $\mathrm{N}$-terminal truncated $\operatorname{ssg} A$ gene was then gelpurified. The protein fusion vector, pMAL-c (New England Biolabs), was digested with EcoRI, blunt-ended by filling the 5 overhangs using T4 DNA polymerase, and then digested with HindIII in the polylinker region. The two DNA fragments were ligated, introduced into $E$. coli $\mathrm{DH} 5 \alpha$, and the transformants were selected for ampicillin resistance. pMGC is expected to direct the synthesis of a fusion protein of $57 \mathrm{kDa}$ which consists of the N-terminal $42 \mathrm{kDa}$ portion of MBP (deleting its signal sequence) and the C-terminal 119 amino acid residues of the $S$ sgA protein. The protein gene fusion point between the insert and the vector plasmid was verified by nucleotide sequencing with a commercial malE primer (New England Biolabs). In addition, overexpression of the fusion protein (expected size $57 \mathrm{kDa}$ ) in the E. coli pMGC1 transformant in the presence of IPTG was confirmed by SDSPAGE analysis (see below).

Purification of MBP-SsgA fusion protein. An overnight culture of E. coli DH5 $\alpha(\mathrm{pMGC1})$ was diluted 50 -fold into $100 \mathrm{ml}$ Luria broth containing $0.2 \%(\mathrm{w} / \mathrm{v})$ glucose and ampicillin. The diluted culture was shaken at $37^{\circ} \mathrm{C}$. When the $\mathrm{OD}_{600}$ reached approximately 0.5 , IPTG was added and the incubation continued for $3 \mathrm{~h}$. Cells were collected by centrifugation at $5000 \mathrm{~g}$ for $10 \mathrm{~min}$, washed once with $10 \mathrm{mM}$ Tris/ $\mathrm{HCl} \mathrm{pH} \mathrm{7.5} \mathrm{containing} 150 \mathrm{mM} \mathrm{NaCl}$, and then suspended in a column buffer $(20 \mathrm{mM}$ Tris $/ \mathrm{HCl}$ pH 7.4, $200 \mathrm{mM}$ $\mathrm{NaCl}, 10 \mathrm{mM} \beta$-mercaptoethanol, $1 \mathrm{mM}$ sodium azide). Cells were disrupted by sonication as described above and then debris was removed by centrifugation at $12000 \mathrm{~g}$ for $30 \mathrm{~min}$. The supernatant was loaded onto an amylose resin (New England Biolabs). The bound MBP-SsgA fusion protein was eluted using the column buffer containing $10 \mathrm{mM}$ maltose. The eluted fusion protein was dialysed extensively against the column buffer without maltose, and then re-subjected to the affinity chromatography procedure as described above. The resulting purified fusion protein ( $>95 \%$ pure) was dialysed against $20 \mathrm{mM}$ potassium-phosphate-buffered saline (PBS) $\mathrm{pH} 7 \cdot 2$. All the above procedures were carried out at $0-4{ }^{\circ} \mathrm{C}$.

Preparation of antiserum. A white rabbit was immunized with approximately $0.5 \mathrm{mg}$ purified $\mathrm{MBP}-\mathrm{Ssg} \mathrm{A}$ fusion protein in complete Freund's adjuvant. Subsequent intradermal injections with adjuvant were performed after 3,5 and 7 weeks. The rabbit was bled $10 \mathrm{~d}$ after the last injection. Control preimmune serum was obtained before the first 
injection. The resultant antiserum contained polyclonal antibodies against both MBP and SsgA since it reacted strongly to the mature MBP of $43 \mathrm{kDa}$ present in $E$. coli crude extract, and to a protein of $15 \mathrm{kDa}$ corresponding to the expected size of SsgA in a crude extract derived from S. griseus. Weak reactions with several protein bands were also observed in S. griseus. Control preimmune serum reacted with a few protein bands but not at all with the $15 \mathrm{kDa}$ protein band. The antiserum was used without removing the anti-MBP antibodies since SsgA was fully separated from MBP following SDS-PAGE.

General reproducibility. The results shown in each figure were all repeated two or more times to confirm the reproducibility.

\section{RESULTS}

\section{Expression and localization of SsgA protein}

The $s s g A$ gene encodes a small acidic polypeptide (calculated isoelectric point 4.3) composed of 136 amino acid residues (Fig. 1). In initial studies the expression of the SsgA protein was determined using Western blotting with polyclonal antibodies against the protein. In submerged cultures in DM1 medium, the expression of SsgA (Fig. 2a, right) was associated with massive sporulation $\left(5 \times 10^{8}\right.$ spores $\mathrm{ml}^{-1}$ at $48 \mathrm{~h}$ as determined microscopically). In contrast, the increase in SsgA protein was much less pronounced in DMCY medium (Fig. 2a, left), in which sporulation was severely suppressed $\left(<1 \times 10^{6}\right.$ spores $\left.\mathrm{ml}^{-1}\right)$. Likewise, the level of SsgA protein increased along with cell ageing on DM1 but not DMCY agar (Fig. 2b). Formation of aerial mycelia commenced at $24 \mathrm{~h}$ and coincided with accumulation of the SsgA protein. Expression of the SsgA protein therefore appears to be linked with morphological development of $S$. griseus in both liquid and solid culture. In order to study the cellular localization of the SsgA protein, crude extract obtained from cells of B2682 grown for $24 \mathrm{~h}$ in DM1 medium was separated into cytoplasmic and membrane fractions and subjected to Western blotting analysis. SsgA protein was found to be present exclusively (more than 95\%) in the cytoplasm (Fig. 3).

\section{SsgA protein expression in mutant cells}

The mutant SY1 is characterized by the ability to sporulate in nutritionally rich media, such as DMCY, in which sporulation of the wild-type strain is normally suppressed (Kawamoto \& Ensign, 1995a). Another mutant, BB51 (afs), is defective in both sporulation and streptomycin production, but the impaired ability is restored completely by the addition of A-factor. The expression profile of the SsgA protein in these developmental mutants was examined (Fig. 2c). The mutant SY1 exhibited a high level of SsgA protein expression in DMCY medium as well as in DM1 medium. The timing of SsgA expression of mutant SY1 in DMCY was similar to that of its parental strain B2682 in DM1 (data not shown). In contrast, the SsgA protein expression of the afs mutant BB51 remained very low throughout growth in DM1. Addition of A-factor to the growth medium, however, restored expression to the (a)

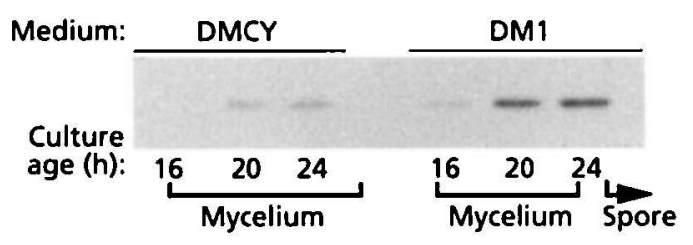

(b)

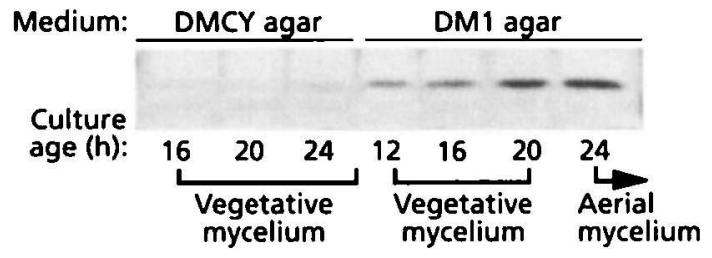

(c)

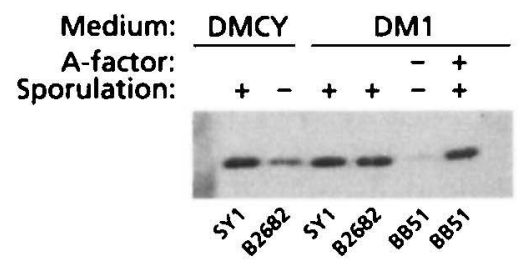

(d)

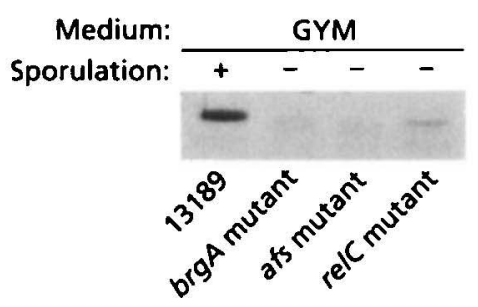

Fig. 2. SsgA protein expression in S. griseus parent and mutant strains in submerged or plate cultures. (a) Submerged cultures of strain B2682. (b) Plate cultures of strain B2682. (c) Submerged cultures of strain B2682 and its mutants. (d) Submerged cultures of strain IFO13189 and its mutants. Crude extracts were prepared from the cells grown for the indicated times (for $24 \mathrm{~h}$ in $\mathrm{c}$ and d) in the indicated media and subjected to SDS-PAGE with a $12 \%$ gel. After electrophoresis, the proteins were transferred electrophoretically to an Immobilon-P membrane and the SsgA protein on the membrane was detected using the anti-SsgA serum as the primary antibody as described in Methods. In (a) and (d) each lane contained $5 \mu \mathrm{g}$ protein, in (b) each contained $20 \mu \mathrm{g}$ protein, and in (c) each contained $10 \mu \mathrm{g}$ of protein except for B2682 grown in DMCY, which contained $25 \mu \mathrm{g}$. Where indicated, A-factor was added to the medium at a final concentration of $40 \mathrm{ng} \mathrm{ml}^{-1}$ in (c). Sporulation was determined after 2 d cultivation.,$+ 5 \times 10^{8}$ spores $\mathrm{ml}^{-1}$ or more; -, less than $1 \times 10^{6}$ spores $\mathrm{ml}^{-1}$.

wild-type levels and was accompanied by abundant spore formation.

Another strain of $S$. griseus, IFO13189, displayed an ssg $A$ gene expression profile similar to that of strain B2682 (data not shown). Several developmental mutants of this strain have been isolated and characterized. 


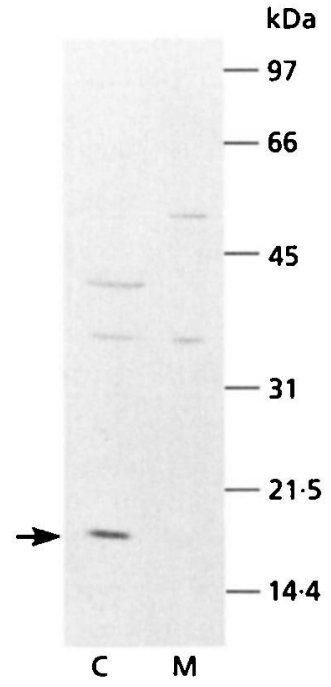

Fig. 3. Cellular localization of the SsgA protein. Crude extract was prepared from cells of B2682 grown for $24 \mathrm{~h}$ in DM1. The crude extract was further fractionated into cytoplasmic (C) and membrane (M) fractions by ultracentrifugation as described in Methods. Samples equivalent to $25 \mu \mathrm{l}$ of the original culture were employed for Western blotting, which was performed as described in Fig. 2. The arrow on the left indicates the position of SsgA protein. Positions of molecular mass standards are shown on the right.

Mutant strain no. 14 (afs) is defective in both sporulation and streptomycin production due to the impaired ability to synthesize A-factor (Ochi, 1987b), and mutant no. 3$3(\mathrm{rel})$ ) exhibits a grossly impaired ability in sporulation and streptomycin production due to a mutation in the rplK (= relC) gene (Ochi, 1990, and unpublished results), and is defective in the ability to accumulate ppGpp. A recently isolated mutant, no. $4(\operatorname{brg} A$; formerly $a b a$ ), is also defective in both sporulation and streptomycin production, possibly due to a failure to ADP-ribosylate certain protein(s) (Ochi et al., 1992; Shima et al., 1996). As Fig. 2(d) shows, these developmental mutants all exhibited no or only slight expression of SsgA protein when cultured in GYM medium and submerged sporulation was severely suppressed $\left(<1 \times 10^{6}\right.$ spores $\mathrm{ml}^{-1}$ at $48 \mathrm{~h}$ ). In contrast, the parent showed massive sporulation $\left(2 \times 10^{9}\right.$ spores $\mathrm{ml}^{-1}$ at $48 \mathrm{~h}$ ) when cultured under the same conditions. In the afs mutant, addition of A-factor to the growth medium restored SsgA expression to the parental level and was accompanied by abundant spore formation (data not shown). These results, together with those from strain B2682, further indicate the significance of SsgA protein expression for the sporulation process in $S$. griseus.

\section{SsgA expression following nutritional shift-down}

Using different $S$. griseus strains (B2682 and IFO13189), nutritional shift-down has been shown to be effective in producing extensive submerged spores (Kendrick \& (a)

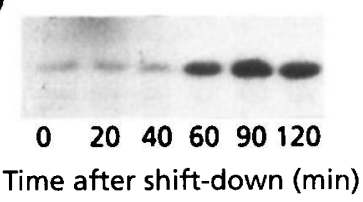

(b)

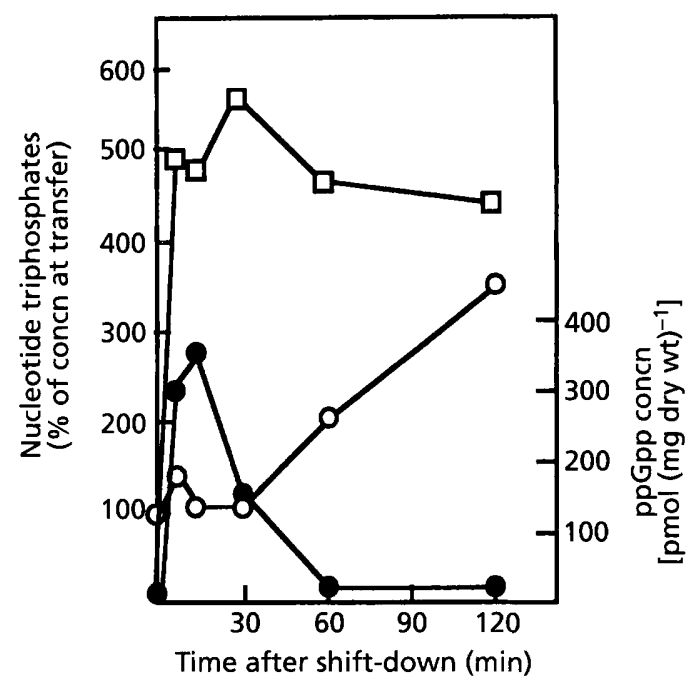

Fig. 4. SsgA protein expression and changes in the intracellular pools of ATP, GTP, and ppGpp in wild-type strain B2682 cells subjected to a nutritional shift-down. (a) Wild-type B2682 was grown in DMCY for $18 \mathrm{~h}$. The cells were harvested by filtration, and quickly transferred into DM1 medium without $0.1 \%$ casein hydrolysate. At the times indicated, the cells were filtered and the crude extracts were prepared for Western blotting as described in Fig. 2. Each lane contained $10 \mu \mathrm{g}$ protein. (b) Cells grown for $18 \mathrm{~h}$ were subjected to nutritional shift-down as described above and ATP ( $\square)$, GTP (O) and ppGpp (O) were determined as described in Methods. Immediately prior to transfer, nucleotide pools of ATP and GTP were 0.7 and

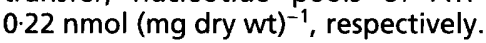

Ensign, 1983; Ochi, 1987a). This sporulation induction technique is particularly useful because at the time of shift-down, defined as time 0 , metabolic events leading to developmental processes are initiated, and can be studied. The effect of nutritional shift-down on SsgA protein expression was therefore examined (Fig. 4). B2682 cells grown to mid-exponential growth phase (for $18 \mathrm{~h}$ ) in DMCY were transferred to DM1 containing no casein hydrolysate. Significant expression of SsgA was detected $1 \mathrm{~h}$ after shift-down. Similar profiles of SsgA expression were observed when cells grown either for $14 \mathrm{~h}$ (early exponential growth phase; approx. $0 \cdot 8 \mathrm{mg}$ dry cell weight $\mathrm{ml}^{-1}$ ) or for $28 \mathrm{~h}$ (early stationary growth phase; approx. $8.5 \mathrm{mg}$ dry cell weight $\mathrm{ml}^{-1}$ ) were employed for the shift-down experiments (data not shown). Under the shift-down conditions used, the intracellular ppGpp level increased markedly (to 360 pmol per mg dry cell wt) 15 min after shift-down whilst the GTP level did not decrease, but increased to over $300 \%$ compared to time 0 (Fig. 4b). Similar experiments were performed using the afs mutant BB51 
(a)



(b)

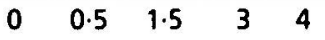

(c)

$\begin{array}{lllll}0 & 0.5 & 1.5 & 3 & 4\end{array}$

(d)



Fig. 5. Effect of A-factor addition on the SsgA protein expression of the afs mutant BB51 after a nutritional shiftdown. The mutant BB51 was grown for $18 \mathrm{~h}$ in DMCY with or without A-factor $\left(40 \mathrm{ng} \mathrm{ml}^{-1}\right)$. The cells were quickly transferred into DM1 without casein hydrolysate in the presence or absence of A-factor and the crude extracts for Western blotting were prepared as in Fig. 2. Each lane contained $5 \mu \mathrm{g}$ protein. The figures below each panel indicate the time $(h)$ after shift-down. (a) No A-factor. (b) A-factor present only in DMCY. (c) A-factor present only in DM1. (d) A-factor present in both DM1 and DMCY.

(Fig. 5), with cells grown in the presence or absence of Afactor. Significant expression of SsgA protein following shift-down was detected only when cells were incubated in the presence of A-factor both before and after shiftdown (Fig. 5d), eventually leading to massive sporulation $\left(5 \times 10^{8}\right.$ spores $\left.\mathrm{ml}^{-1}\right)$ by $48 \mathrm{~h}$. In contrast, the level of SsgA protein expression was low when A-factor was present only either before or after shift-down (Fig. $5 \mathrm{~b}, \mathrm{c}$ ), and low spore titres were produced $\left(<1 \times 10^{6}\right.$ spores $\left.\mathrm{ml}^{-1}\right)$.

\section{Effect of ssgA introduced by plasmid vectors}

We previously reported that the $s s g A$ gene, when introduced in high copy number into B2682, resulted in suppression of sporulation and fragmentation of mycelia (Kawamoto \& Ensign, 1995b). In the present study, we investigated the effect of $s s g A$ gene introduction in both low and high copy number on sporulation, cell morphology, streptomycin production, and SsgA protein expression. The recombinant plasmids pMSA and pLSA carrying the $s s g A$ gene were constructed as described in Methods using the high-copy-number vector pIJ702 and low-copy-number vector pV1, respectively, and used to transform B2682. Cell morphology of a transformant with the low-copy-number plasmid pLSA when grown in liquid DM1 and DMCY media (containing thio- (a)

DM1 medium
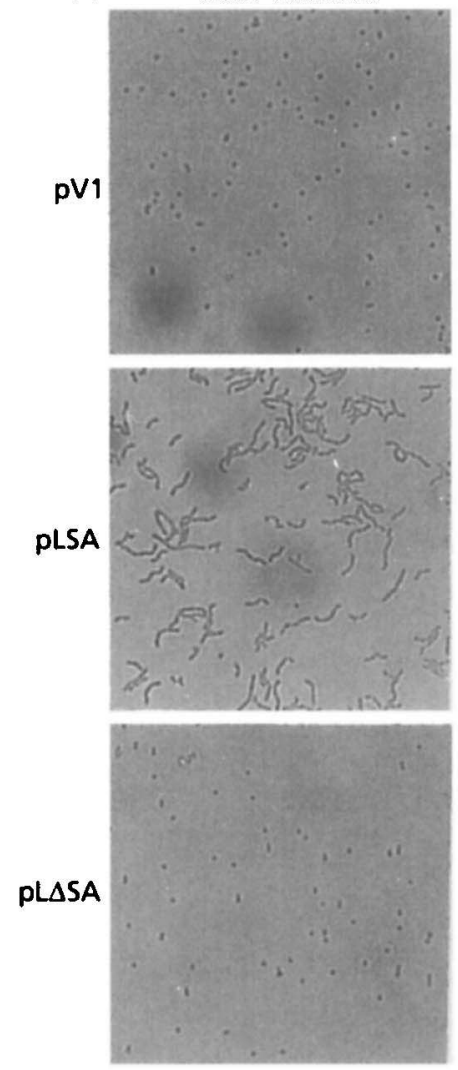

(b)

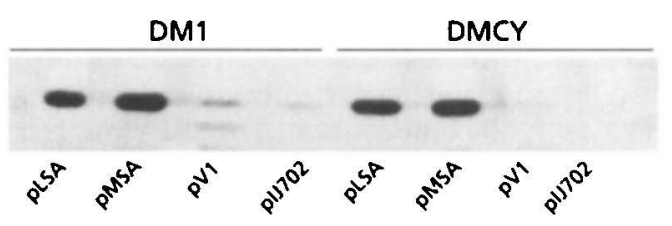

DMCY medium
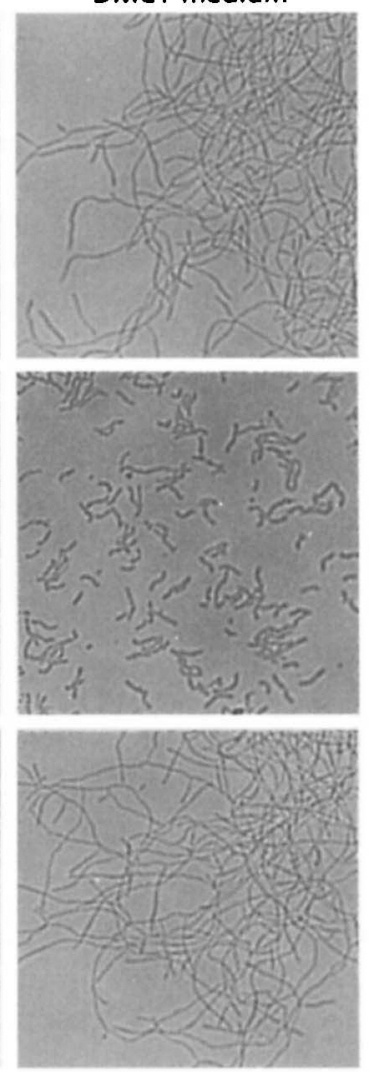

Fig. 6. Cell morphology and SsgA protein expression of B2682 transformants harbouring functional or nonfunctional $s s g A$ genes in low copy number. (a) Cell morphology of transformants harbouring: the vector pV1 (top); pLSA, containing functional ssgA (centre); or $\mathrm{pL} \Delta \mathrm{SA}$, containing mutated ssgA (bottom). Cells were grown for $36 \mathrm{~h}$ in DM1 and DMCY media containing thiostrepton. (b) SsgA protein expression. The cells were grown in the indicated media containing thiostrepton for $24 \mathrm{~h}$. Crude extracts were prepared and used for Western blotting as in Fig. 2. Each lane contained $2.5 \mu \mathrm{g}$ protein.

strepton to prevent the growth of plasmid-free cells) is shown in Fig. 6(a). No significant difference in growth rate between the vector $\mathrm{pV} 1$ transformant and the pLSA transformant was detected. The pLSA transformant showed fragmented growth of pleomorphic rod-shaped cells and no sporulation, not only in DMCY but also in DM1 medium, whereas the transformant harbouring the vector plasmid $\mathrm{pV} 1$ exhibited abundant sporulation in DM1 medium (Fig. 6a). The pMSA transformant also exhibited fragmented growth indistinguishable from 
that of the pLSA transformant (data not shown), as reported previously (Kawamoto \& Ensign, 1995b). When cultured on agar media such as DM1, DMCY and SPY, pLSA and pMSA transformants both formed soft colonies of fragmented non-mycelial cells. These transformants overexpressed SsgA protein throughout the whole of the growth phase examined (10-36 h); results for $24 \mathrm{~h}$ cultures are presented in Fig. 6(b) as an example. The pLSA and pMSA transformants exhibited approximately 5- and 10-fold overexpression of SsgA, respectively, compared with the $\mathrm{pV} 1$ transformant when grown in DM1 medium.

Strain B2682, like S. griseus strain IFO13189 (Ochi, $1987 \mathrm{~b}$ ), produced $15 \mu \mathrm{g}$ streptomycin $\mathrm{ml}^{-1}$ after $3 \mathrm{~d}$ cultivation in SPY medium. Introduction of the lowcopy-number plasmid pLSA (but not vector plasmid pV1) resulted in an increased ability to produce the antibiotic $\left(45 \mu \mathrm{g} \mathrm{ml}^{-1}\right)$. These results indicate that, in contrast to sporulation, the overexpression of SsgA does not suppress streptomycin production.

\section{A mutated ssgA gene introduced by a plasmid vector has no effect}

In order to exclude the possibility that DNA sites on the low-copy-number plasmid pLSA, rather than the ssgA gene product itself, were responsible for the observed fragmented growth and non-sporulating phenotypes, pL $\triangle \mathrm{SA}$, containing a nonfunctional ssgA gene, was constructed as described in Methods (also see Fig. 1) and introduced into strain B2682. The nonfunctional gene possesses a small deletion ( $28 \mathrm{bp}$ ) near its $\mathrm{N}$-terminal end resulting in a frameshift mutation. Transformant cells containing pL $\Delta \mathrm{SA}$ exhibited sporulation in liquid DM1 medium comparable to that of the parent strain containing only the pV1 vector (Fig. $6 \mathrm{a}$ ). The timing of aerial mycelium formation and sporulation of the pL $\Delta$ SA transformant on DM1 agar was also similar to that of the parent strain, and on DMCY agar it formed hard, smooth, non-sporulating colonies, like the parent. These results indicate unambiguously that the ssgA gene product encoded by pLSA is responsible for the observed phenotypes, i.e. suppression of sporulation and fragmented growth of mycelia in the transformant cells.

\section{DISCUSSION}

The $s s g A$ gene had originally been cloned on the basis of its ability to suppress, when introduced in a multicopy vector, the depressed sporulation phenotype of mutant SY1 on nutritionally rich media (Kawamoto \& Ensign, 1995a). Although the nature of the mutation in the SY1 mutant has not been comprehensively characterized, in the present study we have demonstrated the significant role of the $s s g A$ gene product in both sporulation and cell division. This conclusion has been reached from two different observations: (1) a close correlation between SsgA protein accumulation and the onset of sporulation; (2) lack of SsgA accumulation in certain developmental mutants. Although overexpression of SsgA inhibited sporulation without blocking streptomycin production, it remains unknown whether in wild-type cells SsgA regulates not only morphological differentiation but also antibiotic production. Conceivably, accurate adjustment of SsgA content within the cells is required for the normal sporulation process. Further analysis of the ssg $A$ gene using gene disruption techniques is needed in order to elucidate the role of the SsgA protein more fully. The bldA gene encodes a leucine-tRNA which corresponds to an extremely rare TTA codon in streptomycetes (Lawlor et al., 1987; McCue et al., 1992). This gene is reported to be involved in the regulation of sporulation in S. coelicolor A3(2) (Lawlor et al., 1987). The ssgA gene, however, contains no TTA codon, indicating that expression of $s s g A$ is not controlled by the bldA gene at the translational level.

S. griseus IFO13189 accumulates 400-500 pmol ppGpp per mg dry cell weight following nutritional shift-down (Ochi, 1987a). Strain B2682, used in the present study, accumulated a comparable amount $\left(360 \mathrm{pmol} \mathrm{mg}^{-1}\right)$ of ppGpp under similar shift-down conditions (Fig. 4b). It is therefore possible that SsgA protein expression of strain B2682 induced by nutritional shift-down is elicited by the stringent response in terms of ppGpp accumulation. This is supported by the observation that a relC mutant of strain IFO13189 defective in ppGpp synthesis failed to accumulate SsgA protein during its growth cycle. It is rather surprising that unlike strain IFO13189, B2682 did not show a decrease in GTP pool size even under the physiological conditions accompanying a marked ppGpp accumulation. This fact contrasts with the results from previous studies in a variety of Streptomyces species (briefly reviewed by Ochi, 1987a), and could conceivably be due to the fact that strain B2682 (but not IFO13189) has a low GTP content throughout the growth cycle regardless of the culture media used (Ochi et al., 1994; Ochi \& Inatsu, 1995). Indeed, the GTP pool size of B2682 cells growing in DMCY was only one-fourth of the levels detected in strain 13189 when grown under similar conditions (unpublished results). Another intriguing point in the present study is the fact that the afs mutant sporulated and expressed the SsgA protein only when A-factor was present both before and after nutritional shift-down. Although it is premature at present to argue for a role for A-factor in relation to sporulation induced by the shift-down, the results described above imply that Afactor is multi-functional with respect to promoting the developmental processes in this organism, as previously pointed out by Ochi (1987b) working with strain IFO13189.

The fragmented growth caused by the introduction of $s s g A$ raises the possibility that this gene may be involved in septum formation. The $f t s Z$ gene has been reported to play a key role as a positive effector in septum formation in bacteria (Beall et al., 1988; Beall \& Lutkenhaus, 1991; Bi \& Lutkenhaus, 1991; Dai \& Lutkenhaus, 1991; Lutkenhaus, 1993). fts $Z$ homologues have recently been cloned and analysed in S. griseus (Dharmatilake \& Kendrick, 1994) and S. coelicolor (McCormick et al., 
1994). In S. coelicolor, a null mutant of $f t s Z$ is viable and is able to produce aerial hyphae but is unable to sporulate, indicating that FtsZ is required only for sporulation septation. The $s s g A$ gene product, a small highly acidic protein localized in the cytoplasm, is not likely to be a component of the cell division machinery in the cell membrane and shows no sequence homology to FtsZ. It is possible that $s s g A$ is functionally analogous to the $\min E$ gene of $E$. coli, which acts as a topological specificity factor in septum formation during cell division (de Boer et al., 1989, 1990), and that SsgA could interact with a division inhibitor present in Streptomyces; thus overexpression would result in the observed fragmented growth. Further investigations into the functioning of the SsgA protein may provide important information on the mechanistic relationship between sporulation and cell division in Streptomyces, about which very little is currently known.

\section{NOTE ADDED IN PROOF}

The recent discovery of a GTP-binding protein, Obg, in $S$. griseus (Okamoto et al., 1997) provides further support for the role of GTP as a signal molecule in triggering morphological differentiation.

\section{ACKNOWLEDGEMENTS}

This work was supported by a grant from the Basic Research Core System. We are grateful to Dr Hirokazu Matsui, Hokkaido University, for his helpful advice in the preparation of anti-SsgA serum, and to Dr M. J. Bibb for advice on the alkali denaturation method for enhancing transformation efficiency.

\section{REFERENCES}

Babcock, M. J. \& Kendrick, K. E. (1988). Cloning of DNA involved in sporulation of Streptomyces griseus. J Bacteriol 170, 2802-2808.

Babcock, M. J. \& Kendrick, K. E. (1990). Transcriptional and translational features of a sporulation gene of Streptomyces griseus. Gene 95, 57-63.

Beall, B. \& Lutkenhaus, J. (1991). FtsZ in Bacillus subtilis is required for vegetative septation and for asymmetric septation during sporulation. Genes Dev 5, 447-455.

Beall, B., Lowe, M. \& Lutkenhans, J. (1988). Cloning and characterization of Bacillus subtilis homologs of Escherichia coli cell division genes $f t s Z$ and $f t s A$. J Bacteriol 170, 4855-4864.

Bi, E. \& Lutkenhaus, J. (1991). FtsZ ring structure associated with division in Escherichia coli. Nature 354, 161-164.

de Boer, P. A. J., Crossley, R. E. \& Rothfield, L. I. (1989). A division inhibitor and a topological specificity factor coded for by the minicell locus determine proper placement of the division septum in E. coli. Cell 56, 641-649.

de Boer, P. A. J., Crossley, R. E. \& Rothfield, L. I. (1990). Central role for the Escherichia coli minC product in two different cell division-inhibition systems. Proc Natl Acad Sci USA 87, 1129-1133.

de Boer, P., Crossley, R. \& Rothfield, L. I. (1992). The essential bacterial cell-division protein FtsZ is a GTPase. Nature 359, 254-256.
Chater, K. F. (1984). Morphological and physiological differentiation in Streptomyces. In Microbial Development, pp. 89-115. Edited by R. Losick \& L. Shapiro. Cold Spring Harbor, NY: Cold Spring Harbor Laboratory.

Chater, K. F. (1989). Sporulation in Streptomyces. In Regulation of Procaryotic Development, pp. 227-299. Edited by Î. Smith, R. Slepecky \& P. Setlow. Washington, D.C.: American Society for Microbiology.

Chater, K. F. (1993). Genetics of differentiation in Streptomyces. Annu Rev Microbiol 47, 685-713.

Dai, K. \& Lutkenhaus, J. (1991). fts $Z$ is an essential cell division gene in Escherichia coli. J Bacteriol 173, 3500-3506.

Dharmatilake, A. J. \& Kendrick, K. E. (1994). Expression of the division-controlling gene $f t s Z$ during growth and sporulation of the filamentous bacterium Streptomyces griseus. Gene 147, 21-28.

Ensign, J. C. (1988). Physiological regulation of sporulation of Streptomyces griseus. In Biology of Actionmycetes '88, pp. 309-315. Edited by Y. Okami, T. Beppu \& H. Ogawara. Tokyo: Japan Scientific Societies Press.

Hopwood, D. A., Bibb, M. J., Chater, K. F., Kieser, T., Bruton, C. J., Kieser, H. M., Lydiate, D. J., Smith, C. P., Ward, J. M. \& Schrempf, H. (1995). Genetic Manipulation of Streptomyces: a Laboratory Manual. Norwich: John Innes Foundation.

Itoh, M., Penyige, A., Okamoto, S. \& Ochi, K. (1996). Proteins that interact with GTP in Streptomyces griseus and its possible implication in morphogenesis. FEMS Microbiol Lett 135, 311-316.

Katz, E., Thompson, C. J. \& Hopwood, D. A. (1983). Cloning and expression of the tyrosinase gene from Streptomyces antibioticus in Streptomyces lividans. J Gen Microbiol 129, 2703-2714.

Kawamoto, S. \& Ensign, J. C. (1995a). Isolation of mutants of Streptomyces griseus that sporulate in nutrient rich media: cloning of DNA fragments that suppress the mutations. Actinomycetologica 9, 124-135.

Kawamoto, S. \& Ensign, J. C. (1995b). Cloning and characterization of a gene involved in regulation of sporulation and cell division of Streptomyces griseus. Actinomycetologica 9, 136-151.

Kendrick, K. E. \& Ensign, J. C. (1983). Sporulation of Streptomyces griseus in submerged culture. J Bacteriol 155, 357-366.

Kieser, T. (1984). Factors affecting the isolation of cccDNA From Streptomyces lividans and Escherichia coli. Plasmid 12, 19-36.

Laemmli, U. K. (1970). Cleavage of structural proteins during the assembly of the head of bacteriophage T4. Nature 227, 680-685.

Lawlor, E. J., Baylis, H. A. \& Chater, K. F. (1987). Pleiotropic morphological and antibiotic deficiencies result from mutations in a gene encoding a tRNA-like product in Streptomyces coelicolor A3(2). Genes Dev 1, 1305-1310.

Lutkenhaus, J. (1993). FtsZ ring in bacterial cytokinesis. $\mathrm{Mol}$ Microbiol 9, 403-409.

Lydiate, D. J., Malpartida, F. \& Hopwood, D. A. (1985). The Streptomyces plasmid SCP2*: its functional analysis and development into useful cloning vectors. Gene 35, 223-235.

McCormick, J. R., Su, E. P., Driks, A. \& Losick, R. (1994). Growth and viability of Streptomyces coelicolor mutant for the cell division gene ftsZ. Mol Microbiol 14, 243-254.

McCue, L. A., Kwak, J., Babcock, M. J. \& Kendrick, K. E. (1992). Molecular analysis of sporulation of Streptomyces griseus. Gene 115, 173-179.

Ochi, K. (1986). Occurrence of the stringent response in Streptomyces sp. and its significance for the initiation of morphological 
and physiological differentiation. J Gen Microbiol 132, 2621-2631.

Ochi, K. (1987a). Changes in nucleotide pools during sporulation of Streptomyces griseus in submerged culture. J Gen Microbiol 133, 2787-2795.

Ochi, K. (1987b). Metabolic initiation of differentiation and secondary metabolism by Streptomyces griseus: significance of the stringent response (ppGpp) and GTP content in relation to Afactor. J Bacteriol 169, 3608-3616.

Ochi, K. (1990). Streptomyces relC mutants with an altered ribosomal protein ST-L11 and genetic analysis of a Streptomyces griseus relC mutant. J Bacteriol 172, 4008-4016.

Ochi, K. \& Inatsu, Y. (1995). Comparative study of GTP content during growth of Streptomyces griseus and Streptomyces setae in relation to sporulation. Actinomycetologica 9, 184-187.

Ochi, K., Penyige, A. \& Barabas, G. (1992). The possible role of ADP-ribosylation in sporulation and streptomycin production by Streptomyces griseus. J Gen Microbiol 138, 1745-1750.
Ochi, K., Inatsu, Y., Okamoto, S., Penyige, A., Kudo, T. \& Hotta, K. (1994). Characterization of various Streptomyces griseus strains as to aerial mycelium- and submerged spore-formation. Actinomycetologica 8, 79-84.

Okamoto, S., Itoh, M. \& Ochi, K. (1997). Molecular cloning and characterization of the obg gene of Streptomyces griseus in relation to the onset of morphological differentiation. J Bacteriol 179, 170-179.

Sambrook, J., Frisch, E. F. \& Maniatis, T. (1989). Molecular Cloning: a Laboratory Manual, 2nd edn. Cold Spring Harbor, NY: Cold Spring Harbor Laboratory.

Shima, J., Penyige, A. \& Ochi, K. (1996). Changes in patterns of ADP-ribosylated proteins during differentiation of Streptomyces coelicolor A3(2) and its developmental mutants. J Bacteriol 178, 3785-3790.

Received 4 November 1996; accepted 22 November 1996 